\title{
CHEMICAL AND MICROBIOLOGICAL EVALUATION OF ENSILED SUGAR CANE WITH DIFFERENT ADDITIVES
}

\author{
Claudia Eugênia Castro Bravo-Martins ${ }^{1 *}$; Heloisa Carneiro² ; Raúl Jorge Hernán Castro-Gómez ${ }^{3}$; \\ Henrique César Pereira Figueiredo ${ }^{4}$; Rosane Freitas Schwan ${ }^{5}$
}

${ }^{1}$ Part of first author's doctoral thesis in food science, presented to Federal University of Lavras, Brazil; ${ }^{2}$ EMBRAPA, Juiz de Fora, MG, Brazil; ${ }^{3}$ Department of Food Technology and Medicines, State University of Londrina, 36026-460 Londrina, PR, Brazil;

${ }^{4}$ Departament of Veterinary Medicine, Federal University of Lavras, 37200-000, Lavras, MG, Brazil; ${ }^{5}$ Departament of Biology, Federal University of Lavras, 37200-000, Lavras, MG, Brazil

Submitted: February 20, 2006; Returned to authors for corrections: April 27, 2006; Approved: October 13, 2006

\begin{abstract}
Sugar cane silage has a potential for animal feeding, but uncontrolled growth of undesirable microorganisms may cause nutritional losses and affect the animal productivity and health. The objective of this work was to evaluate the microbiological quality and chemical composition of ensiled sugar cane with and without nutritional additives after 30 days of fermentation. Yeasts, filamentous fungi and distinct groups of bacteria were enumerated by plate count methods and the chemical analyzes comprised dry matter, crude protein, fiber content, lignin, and $\mathrm{pH}$. Facultative aerobic bacteria and filamentous fungi were not detected during the fermentative process in any of the treatments. The number of yeasts in five varieties of sugar cane silage without additives was about $6.55 \mathrm{Log}_{\mathrm{CFU} \mathrm{g}}{ }^{-1}$ of silage, and with $1 \%$ ammonium sulfate and $1 \%$ urea were about 5.86 and 5.50 $\mathrm{Log} \mathrm{CFU} \mathrm{g}^{-1}$ of silage, respectively. The lactic acid bacteria (LAB) count without additive was about $8.62 \mathrm{Log} \mathrm{CFU} \mathrm{g}^{-1}$ of silage, and with $1 \%$ ammonium sulfate and $1 \%$ urea the count was about 6.40 and 6.54 $\mathrm{Log}_{\mathrm{CFU} \mathrm{g}}{ }^{-1}$ of silage, respectively. The average percent of dry material in the three treatments was $20.76 \%$. The addition of ammonium sulphate and urea has decreased the microbial load after 30 days but it has increased the total crude protein concentration. Additives also affected neutral detergent fiber, acid detergent fiber and lignin content in all five varieties of sugar cane silage.
\end{abstract}

Key words: sugar cane silage, fermentation, yeasts, lactic acid bacteria

\section{INTRODUCTION}

Sugar cane production consists one of the main Brazilian agribusiness. Besides being used in sugar and alcohol production, nowadays it has drawn more attention as animal feeding. Its advantage for animal feeding includes: i) it is cultivated all over the Brazilian territory, ii) high yield capability and iii) unique ability to maintain consistent quality as a standing crop in the field $(19,27)$. One of the ways of using sugar cane as animal feed is as ensilage. The ensilage process is a technique that consists in preserving foddering plants through acid fermentation adequacy, in which lactic acid bacteria convert soluble sugars into lactic acid (10). Although sugar cane silage has been used as a ruminant feedstuff, there is still room to study and improve sugar cane silage (5). Sugar cane is an unbalanced food, rich in energy and poor in crude protein (about 2 to $3 \%)(9,11)$. Due to low crude protein content of sugar cane, diets based on cane forage require a large quantity of supplemental nitrogen. The economics of feeding sugar cane might be improved by using a less expensive source of crude protein, like urea or ammonia (15).

The quality of ensiled sugar cane mass depends on the speed of acidification of the forage, the composition of ensiled material and on the presence of microbial species that grow

*Corresponding Author. Mailing address: Universidade Federal de Lavras - Dep. de Biologia - cep 37200-000 Lavras, MG - Brasil. Tel.: (35) 38291614. E-mail: bravombr@yahoo.com.br 
during the process. The natural and main fermentative bacteria are the heterofermentative and homofermentative lactic acid bacteria. The number of lactic acid bacteria (LAB) in the ensiled material is highly variable and considerably influences fermentation process (3). LAB includes mainly the species Lactobacillus, Streptococcus, Pediococcus and Leuconostoc. However, in order to the fermentative process successfully occur, anaerobic conditions, adequate substrate, and a sufficient population of LAB are necessary (3).

The major limitation of ensiling sugar cane is due to the metabolic activity of undesirable microorganisms, which are naturally present in the sugar cane crop. Yeasts play an important role on the silage quality. Some species might develop in anaerobic conditions, are capable of surviving at low $\mathrm{pH}$ values (3.5), and are not inhibited by lactic acid (13). These yeasts convert fodder soluble sugars into ethanol, $\mathrm{CO}_{2}$ and water, which results in high dry matter loss and low quality forage (20). The extensive ethanol production when ensiling sugar cane is mainly through fermentation of sugars by yeasts in a metabolic process, which leads to approximately $49 \%$ loss of substratum (11). Produced ethanol represents great energetic cost since it causes a fall of voluntary consumption by the animal after being taken out of the silo. From the total ethanol produced by the yeasts metabolism, 20-30\% may be lost by volatilization and the animals may swallow around 30 to $40 \%$ of the ethanol (19). When swallowed, ethanol might be converted into acetate in rumen and used by the animal, the rest $(60-70 \%)$ carries out a futile cycle without liquid energy production in the metabolism $(13,19)$.

Filamentous fungi are not significant during the fermentation in the ensilage process. However, if present they may contribute to losses on the silo surface during downloading and in cases of inappropriate sealing (21). Fungi, mainly Aspergillus, Fusarium and Penicillium species grow in silages where there is air penetration. Furthermore, these fungi may produce toxins, causing harm to the animals if swallowed.

The objective of the present work was to analyze and quantify the presence of the main microorganisms groups involved in the ensiled sugar cane fermentation in experimental silos, with and without additives, as well as to evaluate the effect of additives on the microbiological and chemical composition quality of the ensiled sugar cane.

\section{MATERIALS AND METHODS}

The experiment was performed in the Laboratory of Microbial Physiology and Genetics of the Biology Department of the Federal University of Lavras. Silages were made with five varieties of sugar cane: SP79-2233, SP80-1836, RB855536, RB835486, RB845257. The varieties of sugar cane approximately 12 months old were picked manually and chopped in a stationary chopper adjusted for cut length of $1 \mathrm{~cm}$. Approximately $4 \mathrm{~kg}$ of chopped material was conditioned into PVC plastic buckets (minisilos), sealed with tight lids containing Bulsen valves for gas scape. Forage was compacted with the aid of wood sticks and the experimental silos were stored at room temperature and analyzed after 30 days of storage. In the moment of ensiling $1 \%$ of ammonium sulphate and $1 \%$ of urea, separately, were mixed to the sugar cane. Three replicates were prepared of each date of sampling.

\section{Microbiological Analyzes}

After 30 days of silage process, $25 \mathrm{~g}$ of sugar cane silage were taken out of minisilos and mixed to $225 \mathrm{ml}$ of $0.1 \%$ of sterile peptone water (3) and homogenized in an orbital mixer for 10 minutes. Subsequent ten-fold dilutions were prepared to counting and quantify the different microbial groups.

\section{Mesophilic Facultative Anaerobic (MFA) and Lactic Acid Bacteria (LAB) Counting}

Total number of mesophilic facultative anaerobic bacteria (MFA) was determined by plate counting using Nutrient Agar [3.0\% meat extract, $5.0 \%$ bacteriological peptone, $13 \%$ agar]. Lactic acid bacteria (LAB) were enumerated using MRS medium (Difco). After inoculation, the plates were incubated at $35^{\circ} \mathrm{C}$ for $48 \mathrm{~h}$.

\section{Filamentous Fungi and Yeasts Counting}

For enumerating filamentous fungi DG18 culture medium [ $8 \%$ glucose, $4 \%$ bacteriological peptone, $0.4 \% \mathrm{KH}_{2} \mathrm{PO}_{4}, 0.8 \%$ $\mathrm{Mg} \mathrm{SO}_{4} .7 \mathrm{H}_{2} \mathrm{O}, 185 \mathrm{ml}$ of glycerol $95 \%, 1 \mathrm{ml}$ of dychloran, 50-75 $\mathrm{mg}$ of chloranfenycol, 13\% agar] was used. Yeasts population was counted in the culture medium YEPG [10\% yeast extract, $20 \%$ bacteriological peptone, $20 \%$ glucose, $13 \%$ agar] at $\mathrm{pH} 3.5$ with addition of ampicilin $\left(200 \mu \mathrm{g} \mathrm{ml}^{-1}\right)$ and gentamicin $(150 \mu \mathrm{g}$ $\mathrm{ml}^{-1}$ ) to avoid bacterial growth. Plates were then incubated at $28^{\circ} \mathrm{C}$ for 5-7 days for filamentous fungi and for 2 days for yeasts counting.

\section{Chemical Analyses}

Dry matter (DM), crude protein $(\mathrm{CP})$, neutral detergent fiber (NDF), acid detergent fiber (ADF) and lignin and $\mathrm{pH}$ were performed as described by Silva (23).

\section{Total Soluble Solids Content $\left({ }^{\circ} \mathrm{Brix}\right)$}

Total soluble solids concentration ( $\left.{ }^{\circ} \mathrm{Brix}\right)$ was evaluated using portable refractometer in the moment of sugar cane minisilos were opened.

\section{Experimental Design and statistical analysis}

Data were analyzed through a completely randomized design with three replicates. It was used a $5 \times 3$ factorial arrangement (5 cultures: varieties SP79-2233, SP80-1836, RB855536, RB835486, RB845257 and three treatments: sugar cane with no additives, 
sugar cane with $1 \%$ of ammonium sulphate and $1 \%$ of urea). Statistical analyzes were carried out using SAEG statistical package, applying the Scott-Knott average test (24).

\section{RESULTS AND DISCUSSION}

Considering that the inhibition of undesirable microorganisms' development is one basic principle to support silage fermentative process quality, it was performed an assessment of the main microbiological groups involved in silage storage of five sugar cane varieties. In this study, the presence neither of mesophilic facultative anaerobic bacteria, nor of filamentous fungi was observed in the silages of the five sugar cane varieties analyzed after 30 days storage in the minisilos.

It was possible to observe high population of yeasts and lactic acid bacteria in the silages with all sugar cane varieties SP79-2233, SP80-1836, RB855536, RB835486 and RB845257 (Table 1). It was not observed a significant difference in the yeast population among the sugar cane varieties silages (Table 1). However, the variety of sugar cane seemed to interfere on the lactic acid bacteria population. It was found $L A B$ population ranging from 6.89 up to $9.70 \mathrm{Log}_{\mathrm{CFU} \mathrm{g}}{ }^{-1}$ of silage among the different sugar cane varieties (Table 1). Lactic acid bacteria preference for a certain sugar cane variety might lead to silage with higher or lower palatability index (28). According to Satter et al. (22), epiphytic bacteria population is changeable, they vary from none to several millions of colony forming unit (Log CFU) per fodder gram.

In the silages of the five sugar cane varieties ensiled without additives, the LAB populations after 30 days of storage was approximately $8.62 \mathrm{Log}_{\mathrm{CFU} \mathrm{g}}{ }^{-1}$ of silage. In the silages containing $1 \%$ of ammonium sulphate and $1 \%$ of urea the $\mathrm{LAB}$ counting was 6.40 and $6.54 \mathrm{Log} \mathrm{CFU} \mathrm{g}^{-1}$ of silage, respectively. In the present study was possible to observe that the additives application has affected the lactic bacteria population. However, the reduction of LAB population did not jeopardize the fermentative process, because it is known that the necessary LAB number to avoid quality losses is around or higher than 6.0 $\mathrm{Log}_{\mathrm{CFU} \mathrm{g}}{ }^{-1}$ of silage (17). According to Lima et al. (14), additives application, such as urea, might improve sugar cane silage quality by decreasing yeast population and, consequently, decreasing ethanol production.

Yeasts population in the silages of the five sugar cane varieties ensiled without additives after 30 days of storage was about $6.55 \mathrm{Log}_{\mathrm{CFU} \mathrm{g}}{ }^{-1}$ of silage. In the silages with $1 \%$ of ammonium sulphate and $1 \%$ of urea, when analyzed at same period of time the yeast population was 5.87 and $5.50 \mathrm{CFU} \mathrm{g}{ }^{-1}$ of silage, respectively. Yeast play an important role in the silage deterioration due to conversion of sugars into ethanol, $\mathrm{CO}_{2}$, and water, consequently generating silages with low contents of lactic and acetic acids $(1,20)$. Yeast populations can reach up to $10^{7} \mathrm{CFU} \mathrm{g}^{-1}$ of silage ( $8 \mathrm{Log} \mathrm{CFU} \mathrm{g}{ }^{-1}$ of silage) during the first
Table 1. Microbial population (Log CFU g-1 of silage) in five varieties of sugar cane ensiled for a 30 days period.

\begin{tabular}{lcccc}
\hline & $\begin{array}{c}\text { Sugar cane } \\
\text { Variety }\end{array}$ & \multicolumn{3}{c}{ Treatments } \\
\hline Mesophilic & & 1 & 2 & 3 \\
anaerobic & SP79-2233 & $0^{\mathrm{Ab}}$ & $0^{\mathrm{Ab}}$ & $0^{\mathrm{Ab}}$ \\
bacteria & & & & \\
& SP80-1836 & $0^{\mathrm{Ab}}$ & $0^{\mathrm{Ab}}$ & $0^{\mathrm{Ab}}$ \\
& RB855536 & $0^{\mathrm{Ab}}$ & $0^{\mathrm{Ab}}$ & $0^{\mathrm{Ab}}$ \\
& RB835486 & $0^{\mathrm{Ab}}$ & $0^{\mathrm{Ab}}$ & $0^{\mathrm{Ab}}$ \\
Lactic acid & RB845257 & $0^{\mathrm{Ab}}$ & $0^{\mathrm{Ab}}$ & $0^{\mathrm{Ab}}$ \\
bacteria & SP79-2233 & $6.89^{\mathrm{Da}}$ & $5.65^{\mathrm{Cb}}$ & $4.74^{\mathrm{Ec}}$ \\
& SP80-1836 & $9.42^{\mathrm{Ba}}$ & $6.43^{\mathrm{Bb}}$ & $5.70^{\mathrm{Dc}}$ \\
& RB855536 & $7.80^{\mathrm{Ca}}$ & $7.30^{\mathrm{Ab}}$ & $6.95^{\mathrm{Cc}}$ \\
& RB835486 & $9.24^{\mathrm{Ba}}$ & $7.23^{\mathrm{Ab}}$ & $8.00^{\mathrm{Ac}}$ \\
Yeasts & RB845257 & $9.77^{\mathrm{Aa}}$ & $5.38^{\mathrm{Db}}$ & $7.30^{\mathrm{Bc}}$ \\
& SP79-2233 & $6.66^{\mathrm{Aa}}$ & $5.40^{\mathrm{Bb}}$ & $6.07^{\mathrm{Ab}}$ \\
& SP80-1836 & $6.45^{\mathrm{Aa}}$ & $6.21^{\mathrm{Ab}}$ & $4.72^{\mathrm{Db}}$ \\
& RB855536 & $6.43^{\mathrm{Aa}}$ & $6.11^{\mathrm{Ab}}$ & $5.62^{\mathrm{Bb}}$ \\
& RB835486 & $6.60^{\mathrm{Aa}}$ & $6.36^{\mathrm{Ab}}$ & $5.69^{\mathrm{Bb}}$ \\
& RB845257 & $6.60^{\mathrm{Aa}}$ & $5.23^{\mathrm{Bb}}$ & $5.41^{\mathrm{Cb}}$ \\
& SP79-2233 & $0^{\mathrm{Ab}}$ & $0^{\mathrm{Ab}}$ & $0^{\mathrm{Ab}}$ \\
& SP80-1836 & $0^{\mathrm{Ab}}$ & $0^{\mathrm{Ab}}$ & $0^{\mathrm{Ab}}$ \\
& RB855536 & $0^{\mathrm{Ab}}$ & $0^{\mathrm{Ab}}$ & $0^{\mathrm{Ab}}$ \\
& RB835486 & $0^{\mathrm{Ab}}$ & $0^{\mathrm{Ab}}$ & $0^{\mathrm{Ab}}$ \\
& RB845257 & $0^{\mathrm{Ab}}$ & $0^{\mathrm{Ab}}$ & $0^{\mathrm{Ab}}$ \\
\hline
\end{tabular}

1: No additives, 2: $1 \%$ ammonium sulfate, $3: 1 \%$ urea.

Means followed by the same letters (capital letters in the columns and small letters in the lines) do not differ ( $\mathrm{p}>0.05$ ) according to ScottKnott test [40].

weeks of ensilage, and the storage for a long period of time normally causes a gradual decrease in its population (12).

The anaerobic conditions and the organic acids concentration are the two factors that affect the yeast survival during silage storage. It has been reported that the presence of oxygen supports the survival and growing of yeasts during silage storage (12) and that high levels of formic or acetic acids decrease their survival during this process (8). Yeasts, unlike the great majority of the microorganisms involved in silages fermentative process, are not controlled by the $\mathrm{pH}$ reduction because they can grow in a wide $\mathrm{pH}$ range from 3 up to 8 (14). In this experiment it was observed that yeast population were not inhibited by the $\mathrm{pH}$ levels reached during ensilage, corroborating with the results reported by Filya et al. (8), Nishino et al. (18), Taylor \& Kung (25). Woolford (31) reported that yeast which were able to ferment sugars besides glucose seem 
to tolerate adverse effects of low $\mathrm{pH}$ and anaerobic conditions better than those ones which are able to ferment glucose only, therefore, they have an extra energy source. Alli et al. (1), while assessing the fermentative profile of sugar cane silages, observed increase in the yeast population of $6.0 \mathrm{Log} \mathrm{CFU} \mathrm{g}^{-1}$ of silage at the time of ensiling to $7.0 \mathrm{Log} \mathrm{CFU} \mathrm{g}^{-1}$ of silage after two days of fermentation. It was observed that yeast population in sugar cane silages was dependent of time, as time advances, the yeast population decreased (20). The results obtained in this experiment confirm this observation, as well as those of Alli et al. (1), Bernardes et al. $(3,4)$ and Pedroso et al. (19).

Data on microbial population and quality of sugar cane silage is still scarce, while data on the microbiology of other fodders silages such as sorghum, wheat, maize, alfalfa, and grasses in general has been reported by several researchers $(8,13,15,18$, $25,29)$. In corn and sorghum silages stored for 90 days, yeasts counting were 3.86 and $4.18 \mathrm{Log} \mathrm{CFU} \mathrm{g}^{-1}$ of silage, respectively, and lactic acid counting was 8.35 and 7.92 $\mathrm{Log}_{\mathrm{CFU} \mathrm{g}}{ }^{-1}$ of silage, respectively. Filya et al. (8) found in wheat, sorghum and corn silages, stored for 60 days, yeast population of 5.6, 5.8, and 5.5 $\log$ CFU $g^{-1}$ of silage, respectively, and lactic acid bacteria counting of 7.3, 6.7, and 7.0 $\mathrm{Log}_{\mathrm{CFU} \mathrm{g}}{ }^{-1}$ of silage, respectively. It was possible to observe from the published data that the yeast and the LAB population in silages is very similar, independently of the fodder used.

The ${ }^{\circ}$ Brix value is an indicator of the amount of soluble solids present in silage. In all five sugar cane varieties analyzed in the time of ensilaging was $21^{\circ} \mathrm{Brix}$. It is possible to infer that there were enough soluble solids for a good microbial fermentative activity during the ensilage process. However, with the application of the additives ( $1 \%$ of ammonium sulphate and $1 \%$ of urea) decreased the activity of lactic acid bacteria and yeast (Table 1), which may have caused lower lactic acid and alcohol production and consequently could have caused a slight increase in $\mathrm{pH}$ value of these silages.

The $\mathrm{pH}$ values in the beginning of sugar cane ensilaging process without additives for all varieties studied SP79-2233 (3.65), SP80-1836 (3.29), RB855536 (3.15), RB835486 (3.64), RB845257 (3.40) ranged from 3.64 to 3.15 . When $1 \%$ of ammonium sulphate was added in the silage the $\mathrm{pH}$ values were from 3.52 to 3.25 in the different varieties used [SP79-2233 (3.31), SP80-1836 (3.52), RB855536 (3.25), RB835486 (3.43) and RB845257 (3.29)]. The addition of urea seems to lead to a similar $\mathrm{pH}$ value independently of the sugar cane variety ensilaged and the range observed was from 3.44 to 3.33 [SP79-2233 (3.39), SP80-1836 (3.44), RB855536 (3.33), RB835486 (3.33), RB845257 (3.44)]. The $\mathrm{pH}$ values in the sugar cane silages containing $1 \%$ of ammonium sulphate reached mean values of 3.34 and in the sugar cane silages with $1 \%$ of urea the $\mathrm{pH}$ values reached mean values of 3.49. Among the organic acids produced during the ensilaging process, lactic acid is the most important, because it has the highest constant of dissociation responsible for $\mathrm{pH}$ decrease. Ammonia production during the ensilaging process can also increase the $\mathrm{pH}$ values (Bernardes et al. (4). In this study, $\mathrm{pH}$ values reached in the sugar cane silages with all varieties, with and without additives were near the range of 3.8 to 4.2 that was recommended by Vilela (30) as being ideal for the preservation of the ensiled material.

The chemical composition of five varieties of sugar cane submitted to different additive treatments were evaluated. The results found are shown in Table 2.

The result of variance analysis for the DM and LIG showed that there were statistical differences among the sugar cane varieties used for ensiling. No significant difference on CP, NDF, and ADF among the studied sugar cane varieties was observed.

Amaral Neto et al. (2) ensiled sugar cane varieties RB72454 and RB806043 and obtained averages of $21.6 \% \mathrm{MS}, 3.5 \% \mathrm{CP}$, $60.6 \% \mathrm{NDF}$ and $40.6 \%$ ADF. Coan et al. (7) evaluated the chemical composition of raw and burnt sugar cane and sugar cane ensiled with $10 \%$ of disintegrated corn with straw and corn cobs and found 27.2\% DM, 50.8\% NDF, 34.7\% ADF and 6.0\% LIG. The DM, CP, NDF, ADF, and LIG found in all five sugar cane varieties with or without additives ( $1 \%$ of ammonium sulphate or $1 \%$ of urea) are presented in Table 3. Variance analysis result for DM, CP, NDF, ADF, and LIG has shown that there were statistical differences among the treatments used in the ensilage. Ammonium sulphate increased in DM concentration of the silages from 20.56 to $21.78 \%$ ( $\mathrm{p}<0.05$ ).

Low protein content constitutes one of the limiting factors in using sugar cane as food for animals, being necessary to add nitrogen source to assure good performance in ruminants (15). Urea is a non-protein nitrogen source used for feeding ruminants (26). In this study, the addition of $1 \%$ ammonium sulfate and $1 \%$ urea significantly increased CP content of the five varieties of sugar cane silage. The CP value in the sugar cane without additives was about $4.07 \%$. With the addition of $1 \%$ ammonium sulfate and $1 \%$ urea, these values raised to $8.63 \%$ and $15.18 \%$,

Table 2. Dry matter (DM), crude protein (CP), neutral detergent fiber (NDF), acid detergent fiber (ADF), and lignin (LIG) after 30 days of silages of five sugar cane varieties with no additives.

\begin{tabular}{lccccc}
\hline $\begin{array}{c}\text { Sugar cane } \\
\text { Varieties }\end{array}$ & $\begin{array}{c}\text { DM } \\
(\%)\end{array}$ & $\begin{array}{c}\text { CP } \\
(\%)\end{array}$ & $\begin{array}{c}\text { NDF } \\
(\%)\end{array}$ & $\begin{array}{c}\text { ADF } \\
(\%)\end{array}$ & $\begin{array}{c}\text { LG } \\
(\%)\end{array}$ \\
\hline SP79-2233 & $18.18^{\mathrm{b}}$ & $4.66^{\mathrm{a}}$ & $69.65^{\mathrm{a}}$ & $40.08^{\mathrm{a}}$ & $10.07^{\mathrm{b}}$ \\
SP80-1836 & $22.84^{\mathrm{a}}$ & $3.94^{\mathrm{a}}$ & $72.42^{\mathrm{a}}$ & $39.28^{\mathrm{a}}$ & $12.49^{\mathrm{a}}$ \\
RB855536 & $23.03^{\mathrm{a}}$ & $3.86^{\mathrm{a}}$ & $73.33^{\mathrm{a}}$ & $40.84^{\mathrm{a}}$ & $8.85^{\mathrm{b}}$ \\
RB835486 & $19.04^{\mathrm{b}}$ & $3.46^{\mathrm{a}}$ & $67.29^{\mathrm{a}}$ & $39.05^{\mathrm{a}}$ & $9.31^{\mathrm{b}}$ \\
RB845257 & $19.70^{\mathrm{b}}$ & $4.45^{\mathrm{a}}$ & $70.94^{\mathrm{a}}$ & $35.95^{\mathrm{a}}$ & $7.86^{\mathrm{b}}$ \\
Mean & 20.56 & 4.07 & 70.73 & 39.04 & 9.72 \\
\hline
\end{tabular}

Means followed by the same letter do not differ according to the Scott-Knott test [40] $(\mathrm{p}>0.05)$. 
respectively. The average protein contents found in this experiment were similar to those observed by Castro Neto et al. (5). From the results obtained in this study limitation of low protein concentration of sugar cane could be solved by providing non-protein nitrogen sources (NPN) during the ensilage process. The additives also have decreased the neutral detergent fiber content (NDF) (Table 3).

Significant differences $(\mathrm{p}<0.05)$ in NDF, ADF and LIG contents among of treatments were observed (Table 3). At beginning of ensilage process NDF content was around $70.73 \%$ and decreased to $66.12 \%$ with $1 \%$ of ammonium sulphate and $67.19 \%$ when the samples had $1 \%$ of urea. The lignin concentration also was different in relation to treatments with ammonium sulphate and urea. Without additive the LIG concentration was $9.72 \%$, when $1 \%$ ammonium sulphate was added to sugar cane the LIG concentration was $9.18 \%$ and with urea was $9.13 \%$. The ADF concentration was also different according to the additives treatment. Silage of pure sugar cane silage presented ADF concentration of $39.04 \%$, while with the addition of $1 \%$ of ammonium sulphate ADF decreased to $37.44 \%$. On the other hand with the addition of $1 \%$ of urea had increased the ADF content up to $40.29 \%$. According to Cheeke (6), treatment with ammonia can dissolves part of lignin and also makes hemicellulose more soluble and allows the cellulose to expand, improving its accessibility to the microorganisms and increasing the fiber's digestibility. Urea, besides being used to increase the crude protein content, can be used as an ammonia source, because the forage surface has enough urease produced by bacteria to convert the urea into ammonia (6).

From the results showed here it could be observed that the microbial load was affected by both sugar cane varieties and addition of ammonium sulphate and urea. The population of lactic acid bacteria was different in relation to sugar cane varieties. The SP79-2233 sugar cane variety showed the lowest population of LAB. Yeasts population was similar in all minisilos containing different sugar cane varieties. The additives have

Table 3. Dry material (DM), crude protein (CP), neutral detergent fiber (NDF), acid detergent fiber (ADF) and lignin (LIG) in three different sugar cane silages after 30 days period of fermentation.

\begin{tabular}{lccccc}
\hline \multirow{2}{*}{ Treatments } & DM & CP & NDF & ADF & LG \\
\cline { 2 - 6 } & \multicolumn{5}{c}{$(\%)$} \\
\hline $\begin{array}{l}\text { Sugar cane with } \\
\text { no additives }\end{array}$ & $20.56^{\mathrm{b}}$ & $4.07^{\mathrm{c}}$ & $70.73^{\mathrm{a}}$ & $39.04^{\mathrm{b}}$ & $9.72^{\mathrm{a}}$ \\
$\begin{array}{l}\text { With 1\% ammonium } \\
\text { sulfate }\end{array}$ & & & & & \\
With 1\% urea & $21.78^{\mathrm{a}}$ & $8.63^{\mathrm{b}}$ & $66.12^{\mathrm{c}}$ & $37.44^{\mathrm{c}}$ & $9.18^{\mathrm{b}}$ \\
\hline
\end{tabular}

Means followed by the equal letters do not differ by the Scott-Knott test (40) $(\mathrm{p}>0.05)$. decreased the microbial load after 30 days but it has increased the total crude protein concentration. Additives also affected neutral detergent fiber, acid detergent fiber and lignin content in the five sugar cane varieties silage. It could be concluded that the presence of additives have shown more difference in the microbiological and chemical characteristics of silage than the sugar cane varieties.

\section{ACKNOWLEDGEMENTS}

The authors thank CNPq (Conselho Nacional de Desenvolvimento Científico e Tecnológico) for doctoral fellowship to the first author and to CAPES for financial support.

\section{RESUMO}

\section{Perfil microbiológico e químico da silagem de cana-de-açúcar com aditivos químicos}

A silagem de cana-de-açúcar apresenta grande potencial para o uso na alimentação animal, entretanto o crescimento de microrganismos não desejáveis durante o processo fermentativo pode causar perdas nutricionais e conseqüentemente afetar o rendimento de produção e também a saúde dos animais. Este estudo objetivou avaliar a qualidade microbiológica e a composição química de silagens de cana-de-açúcar em silos experimentais com e sem a adição de aditivos nutritivos durante o período de 30 dias. Bactérias aeróbicas facultativas e fungos filamentosos não foram detectados nas amostras em nenhum dos tratamentos analisados. A população de leveduras nas silagens das cinco variedades de cana-de-açúcar sem aplicação de aditivos foi em média 6,55 $\log \mathrm{UFC} \mathrm{g}^{-1}$ de silagem e, com aplicação de $1 \%$ de sulfato de amônia e $1 \%$ de uréia foi em média de 5,86 e 5,50 $\log \mathrm{UFC} \mathrm{g}^{-1}$ de silagem, respectivamente. A população de bactérias do ácido lático nos silos sem aditivos foi de 8,62 log UFC g-1 de silagem e nos silos com sulfato de amônio e uréia foi de 6,40 e 6,54 $\log$ UFC $\mathrm{g}^{-1}$ de silagem, respectivamente. A percentagem média de matéria seca das silagens nos três tratamentos foi de $20,76 \%$. A adição dos nutrientes nitrogenados diminuiu a população microbiana após os 30 dias da cana de açúcar ensilada, mas aumentou a concentração de proteína bruta. A presença dos aditivos também afetou a concentração das fibras de detergente neutro e ácida e lignina nas cinco variedades de cana de açúcar ensiladas.

Palavras-chave: silagem de cana-de-açúcar, fermentação, leveduras, bactérias do acido lático.

\section{REFERENCES}

1. Alli, I.; Fairbairn, R.; Baker, B.E.; Garcia, G. The effects of ammonia on the fermentation of chopped sugar cane. Anim. Feed Sci. Technol., 9:291-299, 1983 
2. Amaral Neto, J.; Oliveira, M.D.S.; Lançanova, J.A.C. Composição química e bromatológica da silagem de cana-de-açúcar sob diferentes tratamentos. XXXVII Reunião Anual da Sociedade Brasileira de Zootecnia, Viçosa, 2000, CD ROM.

3. Bernardes, T.F.; Silveira, R.N.; Coan, R.M. Características Fermentativas e Presença de Levedura na Cana-de-Açúcar Crua ou Queimada Ensilada com Aditivo. XXXIX Reunião Anual da Sociedade Brasileira de Zootecnia, Recife, 2002, CD ROM.

4. Bernardes, T.F.; Reis, R.A.; Moreira, A.L. Fermentative and microbiological profile of marandu-grass ensiled with citrus pulp pellets. Scientia Agricola, 62(3): 214-220, 2005.

5. Castro Neto, A.G.; Molina, L.R.; Gonçalves, L.C.; Alencar, C.A.B, Rodrigues, N.M.; Borges, I. e Ferreira, D.A. Avaliação nutricional de silagens de cana-de-açúcar contendo ou não aditivos. (on line) Disponível em: www. ufmg.br/prpg/dow_anais/cien_agrarias/ zootecnia_3/agenor.doc (acesso em: abril de 2003).

6. Cheeke, P.R. Applied Animal Nutrition: Feeds and Feeding. Oregon State University, 1994. p.186-194.

7. Coan, R.M.; Silveira, R.N.; Bernardes, T.F. et al. Composição Química da Cana-de-açúcar crua ou queimada ensilada com aditivo. XXXIX Reunião Anual da Sociedade Brasileira de Zootecnia, Recife, 2002, CD ROM.

8. Filya, I.; Sucu, E. and Karabulut, A. The effect of Propionibacterium acidipropionici, with or without Lactobacillus plantarum, on the fermentation and aerobic stability of wheat, sorghum and maize silages. J. Appl. Microbiol., 97: 818-826, 2004.

9. Evangelista, A.R.; Lima, J.A. Silagens - Do Cultivo ao Silo. Lavras: UFLA, 2000. 200p.

10. Gollop, N.; Zakin, V. and Weinberg, Z.G. Antibacterial activity of lactic acid bacteria included in inoculants for silage and in silages treated with these inoculants. J. Appl. Microbiol., 98:62-666, 2005.

11. Jobim, C.C.; Reis, R.A.; Rodrigues, L.R.A.; Schocken-Iturrino, R.P. Presença de microrganismos na silagem de grãos úmidos de milho ensilado com diferentes proporções de sabugo. Pesq. Agropec. Bras., Brasília, v.32, n.2, p.201-204, fev., 1997.

12. Jonsson, A.; Pahlow, G. Systematic classification and biochemical characterization of yeast growing in grass silage inoculed whith Lactobacillus culture. Anim. Res. Dev., 20: 7-22, 1984.

13. Kung Jr., L.; Taylor, C.C.; Lynch, M.P.; Neylor, J.M. The effect of treating alfalfa with Lactobacillus buchneri 40788 on silage fermentation, aerobic stability, and nutritive value for lactating dairy cows. J. Dairy Sci., 86: 336-343, 2003.

14. Lima, J.A.; Evangelista, A.R.; Abreu, J.G. et al. Silagem de cana-deaçúcar (Saccharum officinarum L.) enriquecida com uréia ou farelo de soja. XXXIX Reunião Anual da Sociedade Brasileira de Zootecnia, Recife, 2002, CD ROM.

15. Lindgren, S.; Pettersson, K.; Kaspersson, A.; Jonsson, A. and Lingvall, P. Microbial Dynamics during aerobic deterioration of silages. J. Sci. Food Agric., 36: 756-774, 1985.
16. McDonald, P.; Henderson, A.R.; Heron, S.J.E. The biochemistry of silage. Chalcombe Publications, New York, 1991, 339p.

17. Muck, R.E. Factors influencing silage quality and they implications for management. J. Dairy Sci., Champaign, 71: 2992-3002, 1988.

18. Nishino, N.; Wada, H.; Yoshida, M.; Shiota, H. Microbial counts, fermentation products, and aerobic stability of whole crop corn and a total mixed ration ensiled with and without inoculation of Lactobacillus casei or Lactobacillus buchneri. J. Dairy Sci., 87: 2563-2570, 2004.

19. Pedroso, A.F.; Nussio, L.G.; Paziani, S.F.; Loures, D.R.S.; Igarasi, M.S.; Coelho, R.M.; Packer, I.H.; Horii, J.; Gomes, L.H. Fermentation and epiphytic microflora dynamics in sugar cane silage. Scientia Agricola, 62(5): 427-432, 2005.

20. Reis, R.A.; Siqueira, G.R.; Bernardes, T.F. Experiência da UNESP Jaboticabal na ensilagem da cana-de-açúcar. I Reunião Técnica sobre Silagem com Cana-de-açúcar. EMBRAPA Pecuária Sudeste, 2004, 13p.

21. Rodrigues, A.A.; Pimavese, O.; Esteves, E.S.N. Efeito da qualidade de variedades de cana-de-açúcar sobre o seu valor como alimento para bovinos. Pesquisa Agropecuária Brasileira, 32: 1333-1338, 1997.

22. Satter, L.D.; Muck, R.; Woodford, J.A.; Jones, B.A. Inoculant research: what has it shown us. In: FORAGE PRODUCTION AND SYMPOSIUM, 12., 1988, Wisconsin Dells. Proceedings... Wisconsin Dell: Wisconsin Forage Council, 1988. p.108-119.

23. Silva, D.J. Análise de alimentos (métodos químicos e biológicos). Viçosa-MG, UFV, 1990. 166p.

24. Scott, A.J.; Knott, M. A cluster analysis method for grouping means in the analyses of variance. Biometrica, Washington, 1974.

25. Taylor, C.C.; Kung Jr., L. The effect of Lactobacillus buchneri 40788 on the fermentation and aerobic stability of high moisture corn in laboratory silos. J. Dairy Sci., 85: 1526-1532, 2002.

26. Torres, L.B.; Ferreira, M.A.; Véras, A.S.C.; Melo, A.A.S.; Andrade, D.K.B. Níveis de bagaço de cana e uréia como substituto ao farelo de soja em dietas para bovinos leiteiros em crescimento. Revista Brasileira de Zootecnia, 32: 760-767, 2003.

27. Torres, R.A.; Costa, J.L. Uso da Cana-de-Açúcar na Alimentação Animal. In: Evangelista, A.R.; Sales. E.C.J. de; Siqueira, G.R.; Lima, J.A. (ed). Uso de Cana-de-açúcar na Alimentação Animal. II Simpósio de Forragicultura e Pastagens - NEFOR (UFLA), 2001.

28. Tosi, H.; Jobim, C.C. Conservação de Forragens: Silagem. In: Biotecnologia Industrial, vol.4, p.491-505, 2001.

29. Umaña, R.; Staples, C.R.; Bates, D.B.; Wilcox, C.J.; Mahana, W.C. Effects of the digestibility of bermudagrass ensiled at two moisture contents. J. Anim. Sci., Champaign, v.69, n.11, p.4588-4601, Nov. 1991.

30. Vilela, D. Aditivos para silagem de plantas de clima tropical. Reunião Anual da Sociedade Brasileira de Zootecnia, Botucatu, 1998, p.73108 .

31. Woolford, M.K. The detrimental effects of air on silage- A review. $J$. Appl. Bacteriol., 68: 101-116, 1990. 